\title{
At the Contours of Corporeality: Critique as Will to Power
}

\section{Bedenselliğ̈in Eșiğinde: Güç İstenci Olarak Eleștiri}

\author{
FULDEN İBRAHIMHAKKIOĞLU
}

Middle East Technical University

Received: I2.04.20I8| Accepted: I8.06.2018

\begin{abstract}
Foucault gives an account of the contrast between Kantian and postKantian critique, which can be summarized as a shift from universality to historicity. This shift to historicity and contingency, for Foucault, opens up the possibility of transgressive critical engagement whereby social transformation can take place. In this essay, it is argued that Nietzsche's work constitutes an example of post-Kantian critique insofar as Nietzsche undertakes critique in the form of revaluation of values through which the historico-corporeal limits are exposed and ways to overcome them are delineated. In this way, Nietzschean critique is an instance of will to power inasmuch as it refers to an endless movement of overcoming. Nietzsche thereby offers critique as a kind of symptomatology that is tied to the corporeality of philosophy.
\end{abstract}

Keywords: Nietzsche, critique, will to power, body, Foucault.

(C) İbrahimhakkığlu, F. (2018). At the Contours of Corporeality: Critique as Will to Power. Beytulbikme An International fournal of Philosophy, 8 (I), I57-170. 


\section{Introduction}

Critique, as Foucault writes in "What is Enlightenment," consists of "analyzing and reflecting upon limits" (2010: 45, emphasis added). He goes on to suggest that whereas the Kantian notion of critique seeks to delineate the limits of knowledge in order to "renounce transgressing," contemporary critique "takes the form of a possible transgression." This transgression, Foucault contends, not only marks the very possibility of social transformation but also goes at the heart of critique as a practice of freedom. And as a practice of freedom, the work of critique is twofold. First, critique aims to "open up a realm of historical inquiry" by way of assuming a "historico-critical attitude," thereby exposing the historical contingency of our morality, identities, and practices. And secondly, critique must "put itself to the test of reality, of contemporary reality," in an experimental spirit, in order "both to grasp the points where change is possible and desirable, and to determine the precise form this change should take." Foucault sums up that critique, by way of its twofold function, "seek[s] to give new impetus, as far and wide as possible, to the undefined work of freedom" (Foucault: 2010: 46).

The shift from "the transgression-renouncing" Kantian critique to "the transgression-seeking" contemporary critique is accounted for by the two modes of investigation that are employed in contemporary critique (and that Foucault himself employs): archeology and genealogy. Critique after Kant, Foucault suggests, will be archeological, and not transcendental: "[I]t will not seek to identify the universal structures of all knowledge or of all possible moral action, but will seek to treat the instances of discourse that articulate what we think, say, and do as so many historical events" (Foucault: 20IO: 46, emphasis added). In other words, post-Kantian critique seeks to delineate historical conditions of possibility that are operative in ways of thinking, speaking, and acting, as opposed to the transcendental conditions of possibility that are universal, not historically specific; and necessary, not contingent. Post-Kantian critique will also be genealogical in that "it will not deduce from the form of what we are what it is impossible for us to do and know; but it will separate out, from the contingency that has made us what we are, the possibility of no longer being, doing, or thinking what we are, do, or think" (Foucault: 2010: 46, emphasis 
added). In this sense, the purpose of critique in exposing limits is to overcome these limits, to precipitate transformation, and to discover ways of becoming otherwise.

Nietzsche's philosophy offers a striking instance of critique of this kind insofar as it embodies this shift from contemplating on transcendental conditions of possibility to historical ones (I989c), from discovering limits of knowledge to seeking possibilities of change. ${ }^{\mathrm{I}}$ The purpose of this essay is to trace this shift in Nietzschean critique and to elucidate the form critique takes in Nietzsche's thought. The form, I argue, is corporeal or bodily, whereas previous (and even some contemporary) discussions on critique tend to rely on non-corporeal terms and a forgetting of the body. Critique, as practiced by Nietzsche, delineates historical limits as the limits of corporeality - that is, as the historical conditions of possibility for the emergence of selves as bodies - and experiments to overcome them, and as such, it is critique as the will to power. ${ }^{2}$ Moreover, we may understand the Nietzschean philosophers of the future, or the free spirits in this way: they are those who are willing to risk intelligibility by not only driving to these limits but also seeking transgression to affirm life by means of embodying the new. In this sense, Nietzschean critique is bound up with corporeality in more ways than one: it is not only a diagnosis that the philosopher-physician gives through an identification of the life-debilitating aspects of sedimented ways of thinking, seeing, and being, but it is also a bodily activity that seeks to enhance the capacities of that body through self-overcoming. The historical conditions of possibility for the self are by no means empty abstractions nor do the knowledge of them serve merely as an intellectual plaything. As Foucault puts it, "knowledge is not made for understanding; it is made for cutting" (1980: 154). Nietzschean critique performs this act of "cutting." The task of genealogy, as critical or 'effective' history (to borrow from Foucault), is to become "a curative science" (I980: 154), tracing and diagnosing the discontinuous and plural forces, elements, and

\footnotetext{
Nietzsche's project of revaluation of all values is indeed his search for possibilities of transformation.

2 Nietzsche explains will to power as a constant movement of overcoming, without a telos. Critique, then, takes this form insofar as it constantly seeks to go beyond limits, yet without an ultimate end.
} 
vectors that comprise the conditions of possibility of the body-self, in an effort to push at the limits for the purposes of self-overcoming.

\section{Transgression: Critique at Limits}

Foucault's contention that the work of critique is "done at the limits of ourselves" goes at the heart of Nietzschean critique (2010: 46, emphasis added), insofar as the theme of self-overcoming runs throughout his corpus. Yet, far from elucidating what critique is, and what it does for Nietzsche, this description of critique only generates more questions: What does it mean to suggest that the work of critique is done at the limits, what are those limits, and what exactly does 'the limits of ourselves' refer to? Perhaps it is not a coincidence that Nietzsche begins On the Genealogy of Morals, which Deleuze calls Nietzsche's rewriting of Kant's The Critique of Pure Reason (Deleuze, 2006: 88), with the following words: "We are unknown to ourselves, we men of knowledge - and with good reason. We have never sought ourselves - how could it happen that we should ever find ourselves?" (Nietzsche, 1989c: 15). Thus, this book on "the origin of our moral prejudices" is a quest to find ourselves, to discover our limits and to what end? - to transgress, or to overcome them.

Let us look more closely at Nietzsche's claim that "we, men of knowledge" are far from being in possession of knowledge when it comes to ourselves. "So," Nietzsche writes, "we are necessarily strangers to ourselves, we do not comprehend ourselves, we have to misunderstand ourselves, for us the law 'Each is furthest from himself' applies to all eternity - we are not 'men of knowledge' with respect to ourselves" (Nietzsche, I989c: I5). What is the reason, one is left wondering, for our profound ignorance of ourselves. ${ }^{3}$ The answer lies in the inquiry Nietzsche undertakes in the rest of this work whereby he maps out the reactive forces and the ways which they disrupt and hinder our abilities of "discovering, inventing, new possibilities of life" (Deleuze, 2006: I0O). Nietzsche's inquiry makes clear that we misunderstand ourselves because the very critical gaze we direct to the limits of our reason, knowledge, and ways of knowing had not yet been directed to the domains of knowledge, tradition, and histo-

3 Deleuze understands this in terms our life-denying commitment to "knowledge," from which he suggests that Nietzsche liberates us by way of liberating "thought" from the hegemony of reason and rationality (2006: IOO-I). 
ry, all of which present the conditions of possibility for the thinking subject to emerge.

Deleuze writes: "Critique has done nothing insofar as it has not been brought to bear on truth itself, on true knowledge, on true morality, on true religion." What is not yet problematized is the very framework that precipitates the Kantian critique whereby "[w]e may criticize pretenders, we may condemn those who trespass on domains, but we regard the domains themselves as sacred" (Deleuze, 2006: 90). Thus, turning the critical gaze onto the framing itself, Nietzsche's genealogy is motivated by the following questions:

$[\mathrm{U}]$ nder what conditions did man devise these value judgments good and evil? And what value do they themselves possess? Have they hitherto hindered or furthered human prosperity? Are they a sign of distress, of impoverishment, of the degeneration of life? Or is there revealed in them, on the contrary, the plenitude, force, and will of life, its courage, certainty, future? (Nietzsche, I989c: 17).

"Genealogy does not only interpret," Deleuze writes, "it also evaluates" (Deleuze, 2006: 6). In reformulating the critical questions regarding value, there is already a revaluation taking place. This is precisely what the Kantian critique forecloses, as Kant "was not able to pose the problem of critique in terms of values" in the way that Nietzsche does. Thus, in the absence of any problematization, "the theory of values has given rise to a new conformism and new forms of submission," contrary to the Nietzschean/Dionysian spirit of transgression. "[T]he notion of value implies a critical reversal," whereby the value of values are brought into question using a revaluation, instead of being taken up as a means for evaluation. Evaluations, for Deleuze, "are not values but ways of being, modes of existence of those who judge and evaluate, serving as principles for the values by which they judge" (Deleuze, 2006: I). As such, there is significance to the fact that the evaluation that is at work here involves a reformulation of the problem for critique in corporeal terms. Framing the question in such a way that asks whether these values which we hitherto had relied upon bear the marks of distress, impoverishment, and degeneration, or that of plenitude, force and will to life already points to a shift; a shift to the body. Not only is the value of these values (i.e., good and evil) 
are brought into question by means of a revaluation, but also a new way of being, a new mode of existence is posited in the very same move. It is in this sense that evaluation is both "critical and creative" (Deleuze, 2006: I), inasmuch as it problematizes the present and the past and opens up new possibilities for the future at the same time. In this particular revaluation, the new way of being, the new mode of existence posited by Nietzsche is one that is attentive to and embracing of life, health, and prosperity, one that brings back the body to the philosophical narrative, one that writes a new narrative whereby thought is always bound up with corporeality rather than with aloof abstractions.

\section{Critique Corporealized: Sickness and Health}

Within the given domain of knowledge, the denial of the body serves as the "condition of 'base' evaluation, 'base' living and thinking" for philosophy (Deleuze, 2006: I). Daniela Vallega-Neu gives an account of how "the question of the body shifts away from its connection with the soul" in modern philosophy following Descartes, "and comes to stand in opposition to thought, while the question of the soul is replaced by consciousness" (Vallega-Neu, 2006: 22). As Foucault puts it, "Historical sense has more in common with medicine than philosophy; and it should not surprise us that Nietzsche occasionally employs the phrase 'historically and physiologically', since among the philosopher's idiosyncrasies is a complete denial of the body" (Foucault, I980: 156). In Nietzschean critique, this denial manifests itself as a sickness in the thought that has been sedimented in western intellectual history, for the denial of the body is nothing but the denial of life itself. Nietzsche, in this regard, by reformulating the question of critique, brings back the lived body that had long been exiled "for the sake of the primacy of reason," and places it "at the center of philosophical reflection" (Foucault, 1980: 156). Nietzsche's self-reflexivity of this move is seen again and again in his writing (he certainly did not take his thought for granted). One such example would be his account of his perpetual state of sickness and its impact on his philosophy in Ecce Homo and The Gay Science.

The way in which Nietzsche speaks of his illness lays bare that it is entangled with his philosophy: 
This stretch of desert, exhaustion, disbelief, icing up in the midst of youth, this interlude of old age at the wrong time, this tyranny of pain even excelled by the tyranny of pride that refused the conclusions of pain - and conclusion are consolations - this radical retreat into solitude as a self-defense against a contempt for men that had become pathologically clairvoyant - this determined self-limitation to what was bitter, harsh, and hurtful to know, prescribed by the nausea that had gradually developed out of an incautious and pampering spiritual diet, called romanticism - oh, who could reexperience all of this? (Nietzsche, 1974: 32-3).

Here we see a reconfiguration of thought in material terms, as Nietzsche equates his bodily sickness with a sickness of thought, namely, romanticism. Physical sickness and philosophical sickness are articulated in the same way, at the same time, in the same utterance. As such, philosophy itself is corporealized: certain kinds of knowledge become painful to know, certain thoughts become nauseating, and one's philosophy gets infected by one's illness. ${ }^{4}$ Thus, it is exposed that philosophy itself has been nothing but "an interpretation of the body and a misunderstanding of the body", inasmuch as it denies its own corporeal roots on its quest to establish a Beyond. Such distracted philosophy is inspired by sickness, of both the body and thought, as physiological needs are guided "under the cloaks of the objective, ideal, purely spiritual" (Nietzsche, I974: 34-5).

If thinking is a bodily activity, and philosophy is an interpretation of that body, there is a kind of symptomatology in which the philosopher engages as she "interprets phenomena, treating them as symptoms whose sense must be sought in the forces that produce them" (Deleuze, 2006: 75). ${ }^{5}$ The symptomatologist, or the philosopher-physician, "has to pursue the problem of the total health of a people, time, race or of humanity" (Nietzsche, 1974: 35). The task for the philosopher then, for Nietzsche, is to attest to these states of health and sickness by translating them into philosophy. Thereby, "[a] philosopher who has traversed many kinds of

4 It is not so much that they "become" as such, but an exposure takes place: this is what they have been all along. The corporealization, then, is on a conceptual level: we begin to see them as such. That is to say, this is an interpretation that rearranges one's relation to philosophy.

5 For Deleuze, in addition to being a symptomatologist, "the philosopher of the future" is also a typologist and a genealogist. 
health, and keeps traversing them, has passed through an equal number of philosophies," for philosophy is bound up with health and sickness, insofar as it is tied to the body. He continues, "[T]his art of transfiguration," that is, transfiguring states of corporeality into thought, "is philosophy" (Nietzsche, 1974: 35). The philosopher, in this sense, is an experimenter; she is the one who is able to look out "from the perspective of sick toward bealthier concepts and values, and conversely, looking again from the fullness and self-assurance of a rich life down into the secret work of the instinct of decadence." Her philosophy is a log of her symptoms, her strife toward health, and her experimentations; she, like Nietzsche, creates her philosophy from out of her "will to health, to life..." (Nietzsche, I989b: 223-4).

Traversing between these bodily states provides the occasion for a journey of thought, which Nietzsche calls 'descent' [Herkunft]. In Thus Spoke Zarathustra, this descent is described as a bodily experience of 'going under', and in Gay Science, it is articulated as the method of inquiry for the philosophers of the future (Mellamphy \& Mellamphy, 2005: 30). ${ }^{6}$ Strikingly, it is also set as the precondition for the revaluation of values (Nietzsche, 1989b: 223), inasmuch as one can experience, and experiment with, the ways in which these values are embodied, thus opening up the possibility for embodying them otherwise. Nietzsche writes:

Only great pain, the long, slow pain that takes its time - on which we are burned, as it were, with green wood - compels us philosophers to descend into our ultimate depths and to put aside all trust, everything good-natured, everything that would interpose a veil, that is mild, that is medium - things in which formerly we may have found our humanity (1974: 36$).^{7}$

Pain $^{8}$ propels this descent whereby we risk losing the values that established our humanity (thus risking our humanity as well). There is a suspension of all values, including trust: "The trust in life is gone: life itself has become a problem" (Nietzsche, 1974: 36). This puts critique and its problematization into a problematical status: why would anyone want

6 He does not use the term "philosophers of the future" in Gay Science, but we may apply this term here to philosopher-physicians based on his account in Beyond Good and Evil.

7 Emphasis added.

8 Physical and psychological, as well as the "pain of knowing": all of these layers come together under the same rubric. 
to risk losing their humanity in this way - and for the sake of what? This risk, the danger of philosophizing at the limits, is something to which Nietzsche keeps coming back. Problematizing the status of the value of truth, he admits that it is "as if we were the first to see [the problem], fix it with our eyes, and risk it. For it does involve risk, and perhaps there is none that is greater." This risk in problematization is articulated regarding an act of "philosophers of the dangerous 'maybes' (I989a: 9-II).

But what is the risk here, and are we willing to take it? Engaging with Foucault's writings on critique, Judith Butler writes:

One does not drive to the limits for a thrill experience, or because limits are dangerous and sexy, or because it brings us into a titillating proximity with evil. One asks about the limits of ways of knowing because one has already run up against a crisis within the epistemological field in which one lives (Butler, 2004: 2015).

In other words, the necessity for critique is brought upon by a crisis in the domain of knowledge one inhabits whereby one experiences a profound conflict between her status as a subject and the very field that produced her as a subject. The crisis here can be understood as the inconsistency between the life-denying, body-debasing philosophy, and Nietzsche's own strife for life and prosperity - his will to power - of which his philosophy is an extension. It can also be understood in relation to "the true world becoming a fable" (Nietzsche, I976a: 485-6), as "the highest values devaluate themselves" to the point of becoming completely untenable, thereby giving way to nihilism. Yet, the philosophy of the future (of the dangerous maybes; one that centralizes the body and takes as its goal an enhanced state of vitality) risks, again and again, falling into unintelligibility and meaninglessness at the face of this normative and epistemological field delineated by two millennia of philosophical work. Perhaps it is for this reason that Nietzsche incessantly asks if he has been understood - for his work attests to the novelty that has not yet been established, a brand new "truth" not yet wholly intelligible, and values that are not yet quite created.

Foucault notes that the "descent attaches itself to the body. It inscribes itself in the nervous system, in temperament, in the digestive apparatus; it appears in faulty respiration, in improper diets, in the debili- 
tated and prostrate body of those whose ancestors committed errors" (Foucault, I980: 147). Descent, therefore, involves unraveling the very thread by which we are interwoven as subjects. It involves rendering that which is most familiar to us strange and no longer being able to rely on age-old definitions to understand ourselves. It involves becoming a stranger to ourselves and risking a sense of groundlessness as one can no longer take comfort in that which is taken for granted. The work of genealogy takes place in "what we tend to feel is without history" (Foucault, I980: I39), and in that, it leads to a sense of uprooting and disorientation. Upon the realization that "[n]othing in man - not even his body - is sufficiently stable to serve as the basis for self-recognition or for understanding other men" (Foucault, I980: 153), one is left in the middle of the ocean with no clear sight of the land.

Yet since this metaphor may evoke horror in those of us who are accustomed to the comforts of habit and the ease that the established ways of seeing, feeling, and providing, it is also liberating image for Nietzsche. Giving an account of " $[h]$ ow to understand our cheerfulness" upon the death of God, the event whereby "the belief in the Christian God has become unbelievable" and an era of nihilism had begun, Nietzsche writes:

[A]t hearing the news that 'the old god is dead', we philosophers and 'free spirits' feel illuminated by a new dawn; our heart overflows with gratitude, amazement, forebodings, expectation - finally the horizon seems clear again, even if not bright; finally our ships may set out again, set out to face any danger; any daring of the lover of knowledge is allowed again; the sea, our sea, lies open again; maybe there has never been such an 'open sea' (Nietzsche, 1974: 199).

While Nietzsche describes this thought of an open sea to invoke "a new and barely describable type of light, happiness, relief, amusement, encouragement, dawn" (1974: 199), the thought that one is left in the middle of the unforgiving ocean may also inspire fear and distress. For Nietzsche, however, it is a necessary move, as what is done is done and we cannot help but live in an era of nihilism. It is now time to sail.

Critique, insofar as it involves a process of revaluation, is no longer an optional activity for the one who finds herself already in the midst of crisis. The work of critique practiced "at the limits of ourselves" proves to 
be very actual, real, limits of experience and the contours of corporeality since the danger is "to risk one's very formation as a subject," as a bodysubject (Butler, 2004: 225). Nietzsche refers to this in the above passage as the risk to lose one's "humanity." This is because the values one brings into question make up a human being (as an intelligible human being). They are the conditions of possibility for the emergence of the subject, conditions through which we understand both ourselves and others. Working at the limits of ourselves, then, entails the risk that we lose ourselves, lose our intelligibility. This is because the field of intelligibility in which we reside and to which we are committed is "rooted in values and thus in a lived reality that shapes living bodies" (Vallega-Neu, 2006: 22). Critique involves a kind of uprooting that may leave one feeling lost and displaced. There are no guarantees that the next step will lead to life enhancement and abundance that the new values that are invented will serve life in ways that the old values never could. But if there is decay, one cannot do other than to find another way or slowly rot and wither away. Such is the movement of life.

\section{Conclusion: Shifting the Contours of Corporeality}

As Nietzsche puts it, "values are generated physiologically" (Marsden, I998: 42), and therefore "every table of values, every 'thou shalt' known to history or ethnology, requires first a physiological investigation and interpretation" (Nietzsche, I989c: 55). Thus the body itself is taken as "the starting point" (I968: 27I). Jill Marsden (I998: 38) writes: "Nietzsche's genealogy is always at some level a genealogy of the body, a 'diagnosis' of its different modalities and regimes." Our limits, at which carry out critique, are exposed to be our corporeal limits insomuch as we are constituted by the values that we embody. Then the question for us becomes, as we 'descend', a reformulation and redirection of the Spinozist/ Deleuzian question: "What can a body do?"

What a body can do is bound up with that body's status as a multiplicitous "social structure" (Nietzsche, 1989a: 26-7), and the will to become otherwise. In its multiplicity, the meaning of the body is ultimately undetermined for Nietzsche, as "it is a correlate and a function of fundamentally heterogeneous psycho-physiological processes, a particular ex- 
pression of the multiple drives and affects of body, rather than immortal, transcendental or metaphysical essence" (Mellamphy \& Mellamphy, 2005: 22). It is ever changing as the site of the play of forces and values. Nietzsche (I968: 380) writes: "Value is the highest quantum of power that a man is able to incorporate." In 'incorporation' the body becomes that which it incorporates. This is why attending to the body will endow the philosopher-physician with the most enriched understanding of life, inasmuch as the body is indeed where life happens.

In revaluating, then, the experimenter-philosopher looks for the ways which these contours of corporeality may be shifted. The fate of values, after all, is bound up with the fate of the body: their incorporation the process in which the subject/body establishes herself. If philosophy hitherto had been a philosophy of sickness, and morality a system of sick values, and if the work of critique is to put them in question, perhaps even transform them, then one has to start with the body. Transgression of these values and fields of intelligibility, then, involves, first and foremost, a bodily transformation.

"The critical instance," Deleuze (2006: 94) writes, "is the will to power, the critical perspective is that of the will to power." As such, critique corresponds to a perpetual self-overcoming, with no end or telos, with regard to the unceasing movement of the will: always toward overabundance, overrichness, constant growth... Thus, unlike Kant, what emerges out of critique is not justification through which we secure our limits (as in self-preservation), but to endlessly transgress them (as in constant growth). Further, inasmuch as willing is bound up with feeling - in that will to power "is the primitive form of affect" (I968: 366) - what emerges out of critique is "another sensibility" (Deleuze, 2006: 94), feeling, thinking, and becoming otherwise. ${ }^{9}$

In conclusion, Nietzschean critique, far from being the activity of the rational subject establishing an incontestable framework, opens up new possibilities for the subject, yet "at the greatest risk." Not only does

9 In fact, Nietzsche describes the state one reaches after 'descent' (i.e. what one becomes through critique) in the following words: "[O]ne returns newborn, having shed one's skin, more ticklish and malicious, with a more delicate taste for joy, with a tenderer tongue for all good things, with merrier senses, with a second dangerous innocence in joy, more childlike and yet a hundred times more subtler than one has ever been before" (1974:30). 
the work of critique take place on the level of sensibility, but it involves constant shifts in the contours of corporeality, for it is bound up with the question of what a body can do, and thus with incorporation. A body can overcome itself, become otherwise, but in so doing, it may risk its intelligibility, its established meaning, and thus its humanity. This is a risk, however, that Nietzsche takes over and over again, and he invites (or better, challenges) us to join him. Are we free spirits willing to sail away in the open seas or weaklings doomed to decay on sinking land?

\section{References}

Butler, J. (2004). What is Critique? An Essay on Foucault's Virtue. The Fudith Butler Reader. (Eds. S. Salih \& J. Butler). Malden, NJ: Blackwell Publishing, 3O2-22.

Deleuze, G. (2006). Nietzsche and Philosophy. (Trans. H. Tomlinson). New York: Columbia University Press.

Foucault, M. (1980). Nietzsche, Genealogy, History. Language, Counter-Memory, Practice: Selected Essays and Interviewes. (Ed. D. F. Bouchard). Ithaca: Cornell University Press, I39-64.

Foucault, M. (2010). What is Enlightenment? Foucault Reader. (Ed. P. Rabinow). New York: Vintage Books, 32-50.

Marsden, J. (1998). Critical Incorporation: Nietzsche and Deleuze. Fournal of Nietzsche Studies, 16, 33-48.

Mellamphy, D. \& Mellamphy, N. B. (2005). In 'Descent' Proposal: Pathologies of Embodiment in Nietzsche, Kafka, and Foucault. Foucault Studies, 3, 27-48.

Nietzsche, F. (1968). Will to Power. (Trans. W. Kaufmann). New York: Vintage Books.

Nietzsche, F. (1974). The Gay Science. (Trans. W. Kaufmann). New York: Vintage Books.

Nietzsche, F. (1976a). The Treilight of the Idols. (Trans. W. Kaufmann). The Portable Nietzsche. (Ed. W. Kaufmann). London: Penguin Books.

Nietzsche, F. (1976b). Thus Spoke Zarathustra. (Trans. W. Kaufmann). The Portable Nietzsche. (Ed. W. Kaufmann). London: Penguin Books.

Nietzsche, F. (1989a). Beyond Good and Evil. (Trans. W. Kaufmann). New York: Vintage Books. 
Nietzsche, F. (1989b). Ecce Homo. (Trans. W. Kaufmann). On the Genealogy of Morals \& Ecce Homo. (Ed. W. Kaufmann). New York: Vintage Books.

Nietzsche, F. (1989c). On the Genealogy of Morals. (Trans. W. Kaufmann \& R. J. Hollingdale). On the Genealogy of Morals \& Ecce Homo. (Ed. W. Kaufmann). New York: Vintage Books.

Vallega-Neu, D. (2006). The Bodily Dimension in Thinking. Albany: SUNY Press.

Öz: Foucault'ya göre Kant ve Kant sonrası eleștiri evrensellik ilkesinden tarihsellik ilkesine bir geçiş olarak özetlenebilir. Tarihselliğe ve olumsallığa geçiş, sosyal dönüșümü olanaklı kılan transgresif eleștiri olasılığını doğurur. Bu yazı, Nietzsche'nin düșüncesini Kant sonrası eleștirinin önemli bir örneği olarak inceler. Nietzsche'de eleștiri, tüm değerlerin yeniden değerlendirilmesi olarak karşımıza çıkar. Bu yeniden değerlendirme pratiği, tarihsel ve maddesel limitleri görünür kıldığı ölçüde bu limitlerin aynı zamanda ötesine geçme yollarının da açınsaması niteliğindedir. Dolayısıyla Nietzscheci eleștiri, sonu olmayan bir üstün gelme çabasına tekabül ederek bir tür güç istenci konumundadır. Böylece Nietzsche felsefenin bedenselliğinden yola çıkarak eleștiriyi bir tür semptomatoloji olarak sunar.

Anahtar Kelimeler: Nietzsche, eleștiri, güç istenci, beden, Foucault. 